原著

\title{
耳鼻咽喉科診療所におけるめまい診療の実態
}

\author{
小林謙・五十嵐岳史
}

\section{Analysis of vertiginous patients seen at an ENT clinic}

\author{
Yuzuru Kobayashi, Takefumi Igarashi \\ Kobayashi ENT clinic
}

We performed a demographic analysis of 2293 vertiginous patients seen at our clinic from February 1995 to November 2005. While a definitive diagnosis could be made in 1287 cases $(56 \%)$, the diagnosis remained tentative in $622(27 \%)$, and the cause diagnosis remained unknown in 384 cases (17\%). The most common vertiginous disease was benign paroxysmal positional vertigo (456 cases), followed in prevalence by Meniere's disease (232 cases). Most patients had visited other medical facilities before visiting our clinic. Analysis of the medical facilities visited by the patients suggested that the vertiginous patients visited both physicians and otolaryngologists; while. physicians saw the patients in primary care settings, otolaryngologists examined the patients at general hospitals and university hospitals. This discrepancy may complicate the care of vertiginous patients.

Key words: vertigo, demographic analysis, clinic

\section{はじめに}

国民衛生の動向によるとめまいの有訴率は人口 千人に対し 20.5 とされ ${ }^{1)}$, めい患者の診療はプ ライマリ・ケアの重要な課題である。めまい患者 は耳鼻咽喉科ばかりでなく，内科・脳神経外科・ 救急外来などいろいろな診療科を受診し, 原因も 様々で診療が複雑多岐となり，めまいのプライマ リ・ケアが十分に行われているか問題となる。し かしながら，プライマリ・ケアの重要な担い手で ある耳鼻咽喉科診療所におけるめまい診療の実態 を検討した報告は少なく，めまいのプライマリ・ ケアの実態が十分に明らかにされていない。我々 の施設は開院以来めまい患者の診療を積極的に行 ってきたが，今回当院におけるめまい患者の診療 の実態を調査し, 一般耳鼻咽喉科診療所における

小林耳鼻咽喉科内科クリニック
めまいのプライマリ・ケアの現状を検討した。

\section{対象と方法}

対象は平成 7 年 2 月から平成 17 年 12 月までの 10 年11力月の間に当院に初診登録された 21925 例の うち, ENG 検査を含む神経耳科学的検査を行っ た2293例（男753例，女1540例）である。検討し た項目は，年齢及び性別統計，疾患別統計，当院 受診以前の医療機関の受診歴及び診療圈分析であ る。

\section{結 果}

めまい患者数の推移を図 1 に示す。めまい患者 数は平成 7 年より平成 10 年までは年間ほぼ 220 例 であった。その後, 平成11年が185例, 平成12年 から14年は150例前後と，めまい患者は減少した が，平成15年より増加し平成15年には270例，平 成17年には301例であった。

性別を見ると，すべての年度で女性の症例が多 


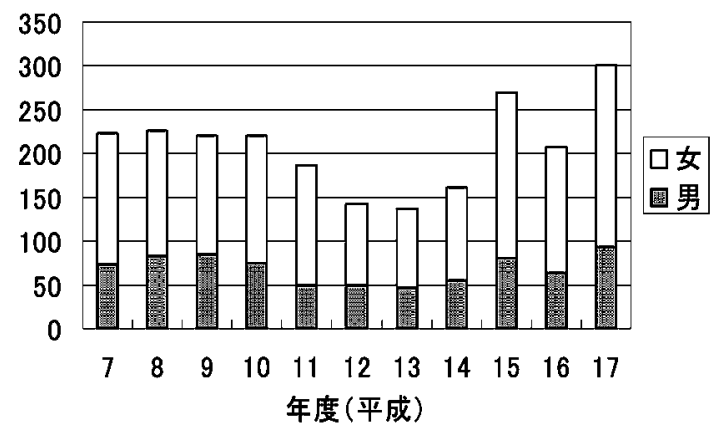

図1 めまい患者数の年次推移 (総数2293例)

横軸が年度を縦軸は症例数を示す。

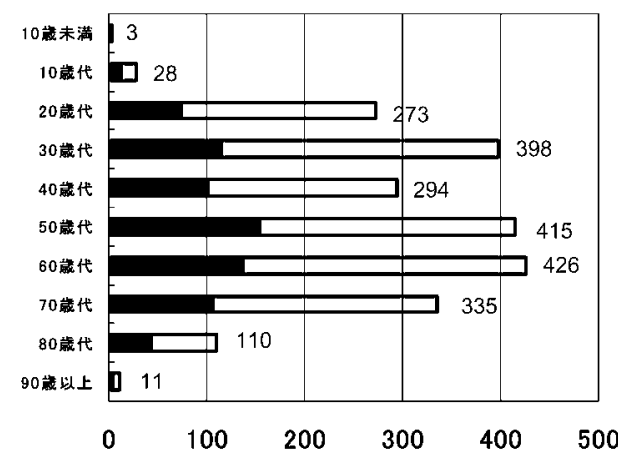

図 2 年齪別めまい患者数（総数2293例） 縦軸は各年代を示し, 横軸は症例数を示 す。グラフの数字は症例の実数を示す。

く，全症例の男女比は $1 ： 2.0$ であった。

年齢別のめまい患者数を図 2 に示した。20代か ら70代までの患者が多く，50代415例，60代426例 と50～60代に山を認めた。一方で30代も398例と 多かった。これに対し，80代は少なく，特に，20 歳未満と90歳以上の症例は非常に少なかった。全 症例 2293 例中の65歳以上の高齢者は693例 (30.2\%) であった。

診断では，確実に診断ができたのは1,287例 (56\%)であり，疑い例は622例 $(27 \%)$ であった。 384 例 $(17 \%)$ の症例では診断ができず，原因不 明であった。診断確実例・診断疑い例を合わせた 1909例のうち末梢性疾患は1257例 $(66 \%)$ と 3 分 の 2 を占め, 中枢性疾患は 109 例 $(6 \%)$ と少な かった。末梢性・中枢性以外のめまいは543例 (28\%) であった。

めまいの原因疾患の内訳を図 3 に示した。最も

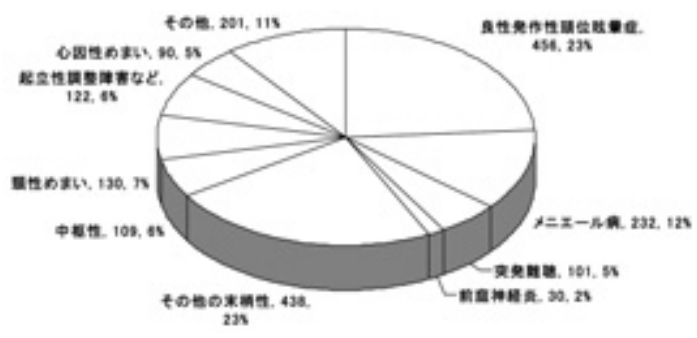

图 3 めまいの原因疾患（総数1909例） めまいの原因疾患の内訳を示す。各疾患の 下の数字は, 症例数と比率を表す。

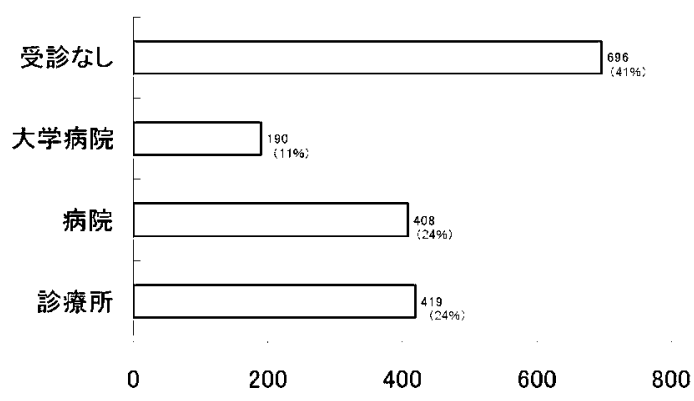

図 4 医療機関受診歴（総数1713例）

我々の施設を受診する前に症例が受診した 医療機関の内訳を表す。縦軸は医療機関を 示し，受診なしは我々に施設を受診する前 にどこの医療機関も受診しなかった患者を 示す。横軸は症例数を示す。各グラフの数 字は症例数と比率を表す。

多かったのは良性発作性頭位めまい（BPPV）で 456例 $(23 \%)$ であった。次いでメニエール病 (MD) が232例（12\%）であり，両者を合わせる と末梢性めまい疾患のほぼ半数であった。突発性 難聴ならびに前庭神経炎は，それぞれ，101例 (5\%)，30例（2\%）と少なかった。末梢性・中 枢性以外のめまいの原因疾患は，頸性めまい130 例 $(7 \%)$ ，起立性調節障害122例（6\%)，心因 性めまい90例（ $5 \%$ ）であった。

中枢性疾患の内訳を表 1 に示した。中枢性疾患 で最も多かったのは脳血管障害の24例で中枢性疾 患の $22 \%$ 占めていた。次いで, 椎骨脳底動脈循 環不全，聴神経腫瘍・脳腫瘍で，それぞれ17例 (16\%)，16例 (15\%) であった。これらで中枢性 疾患のほぼ半数を占めていた。

我々の施設を受診する以前の他医療機関の受診 
表 1 中枢性疾患内訳

\begin{tabular}{|l|c|}
\hline 中枢性疾患 & 症例数 \\
\hline 脳血管障害 & 24 \\
\hline 椎骨脳底動脈循環不全 & 17 \\
\hline 聴神経腫瘍・脳腫瘍 & 16 \\
\hline 脊䯣小脳変性症 & 8 \\
\hline 本態性振戦 & 5 \\
\hline その他 & 39 \\
\hline
\end{tabular}

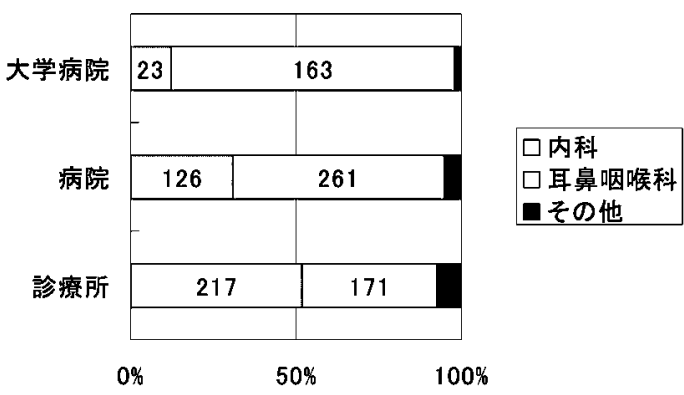

図 5 受診科の比率 (総数1017例)

我々の施設を受診する以前に他の医療機関 を受診した既往のある症例の受診した診療 科の内訳を診療所・一般病院・大学病院別 に示す。縦軸は医療機関を示し, 横軸は比 率を示す。グラフの数字は症例数を表す。

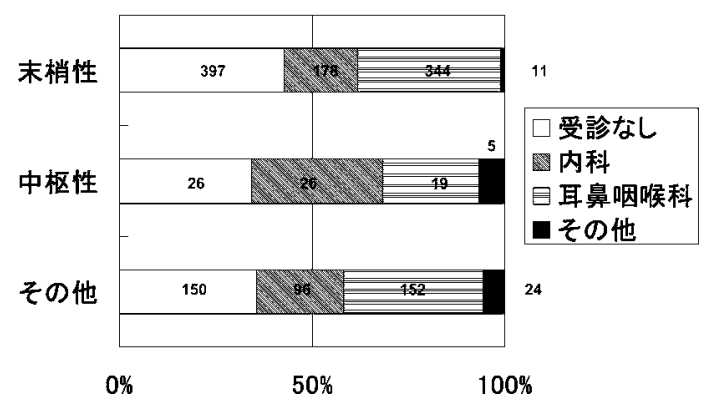

図 6 めまい疾患別の受診科前歴

末梢性・中枢性・その他のめまい別に我々 の施設を受診する以前の受診した診療科を 示す。縦軸は疾患を，横軸は比率を示す。 グラフの数字は症例数を表す。

の有無を図 4 に示した。受診歴が明らかであった 1713例のうち，他の医療機関を受診していなかっ た症例は696例 $(41 \%)$ で，半数以上が，我々の

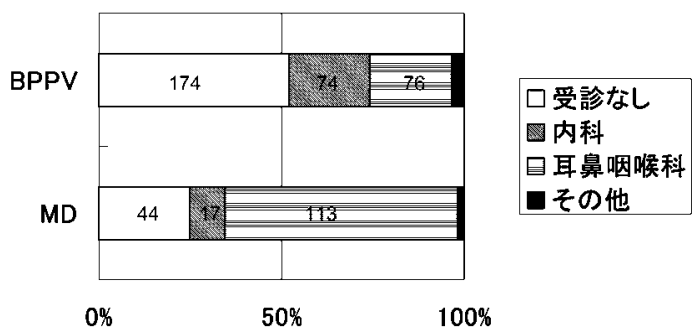

図 7 良性発作性頭位めまいとメニエール病受診 歴の比較

良性発作性頭位めまい（BPPV）とメニエ 一ル病 (MD) 症例それぞれの我々の施設 を受診する以前の受診した診療科を示す。 縦軸は疾患を, 横軸は比率を示す。グラフ の数字は症例数を表す。

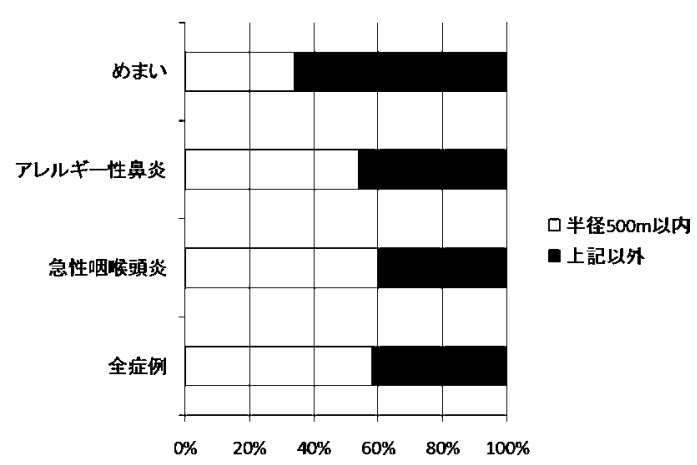

図 8 疾患別の診療圈分析

全症例・めまい・アレルギー性鼻炎・急性 咽喉頭炎各症例の診療圈分析。縦軸は疾患 を横軸は比率を示す。

医療機関を受診する以前に他の医療機関を受診し ている既往があった。医療機関別に見ると，診療 所と一般病院はほほ同数でそれぞれ419例 (24\%)，408例 (24\%) であった。一方で大学病 院を受診していたものも190例（11\%）あった。

我々の施設を受診する以前に他の医療機関を受 診した既往のある1017例の受診科の比率を医療機 関別に図 5 に示した。診療所，一般病院，大学病 院ともに内科あるいは耳鼻咽喉科を受診した症例 がほとんどであったが，医療機関別に見ると，内 科を受診した症例と耳鼻咽喉科を受診した症例の 比率には差が認められた。診療所では内科を受診 した症例の比率は約半数の 217 例 $(51 \%)$ と耳鼻 咽喉科を受診した症例171例（40\%）を上回って 
いた。一方，一般病院では耳鼻咽喉科を受診した 症例が増加し261例 $(64 \%)$ で，内科を受診した 症例126例 $(30 \%)$ の 2 倍近くあった。大学病院 ではほとんどの症例が耳鼻咽喉科を受診しており その症例数は163例 $(86 \%)$ であり，内科を受診 した症例は23例 $(10 \%)$ であった。

末梢性・中枢性・その他のめまいの別に受診科 前歴の比率を図 6 に示した。末梢性・中枢性・そ の他の間で受診科に大きな違いは認められなかっ たが，中枢性疾患では，末梢性やその他に比べ内 科受診歴の比率が高い傾向が認められた。

末梢性めまいの半数以上を占める BPPV およ びMD の受診前歴を図 7 に示した。BPPVでは約 半数の174例 $(52 \%)$ が他の医療機関への受診が なかったのに対して，MD では他の医療機関を受 診しなかった症例は44例 $(25 \%)$ と半分の比率で あった。内科と耳鼻咽喉科の受診率を見ても，

BPPV では内科・耳鼻咽喉科ともにそれぞれ74例 (23\%)，76例 (23\%) 認められたのに対し，MD では，耳鼻咽喉科を受診した症例が113例 (64\%) と多く，内科の受診は 17 例 $(10 \%)$ と少なかった。

診療所の診療圈と言われる診療所所在地から半 径 $500 \mathrm{~m}$ 内に居住する患者の比率を図 8 に示し た。今回のめまい症例では半径 $500 \mathrm{~m}$ 内に居住 する症例の比率は，10年11ヶ月の全症例における $58 \%$ に比べ34\%と少なかった。対照とした，アレ ルギー性鼻炎患者では $54 \%$ ，急性咽喉頭炎患者で は60\%といずれもめまい症例の比率より高く, 全 症例の比率に近い值であった。

\section{考察}

有訴率の高いめまいは外来で遭遇することも多 い疾患であり，めまいの診療はプライマリ・ケア における重要な課題である。しかしながら，めま い患者の受診動態の検討は総合病院 ${ }^{2) ~ 4) ~}$ や学病 院耳鼻咽喉科 ${ }^{5) \sim 13)}$ のものがほとんどで，プライマ リ・ケアの重要な担い手である耳鼻咽喉科診療所 における検討は少ない。今回耳鼻咽喉科診療所に おけるめまい患者の受診動態を知る目的で, 我々 の診療所におけるめまい患者の統計的検討を行っ た。

大学病院，総合病院・専門病院での検討では, めまいの年間受診患者数は200例〜 500例，耳鼻咽 喉科におけるめまい患者の割合はおおよそ5〜 $10 \%$ とされるが2) 13), 我々の施設でのめまい患者
の年間患者数・比率はともに，従来の報告と同じ であった。我々の施設のめまい患者に対する検 査・診療体制は耳鼻咽喉科診療所よりは総合病院 耳鼻咽喉科のそれに近く，今回の数值は一般的な 耳鼻咽喉科診療所におけるめまい症例の患者数 · 比率を示すものではないが，診療所においても積 極的にめまい診療を行うことにより大学病院・総 合病院と同程度の症例数のめまい患者が受診する ということを今回の検討は示唆している。

年齢別でのめまい患者数は，従来の報告と同じ く，50代・60代に山があり，20歳未満と90歳以上 の症例が少なかった。65歳以上の症例の比率は $30.2 \%$ あり，近年高齢のめまい患者の受診率が 高くなっているという報告とほぼ同じである ${ }^{14)}$ 国民衛生の動向によれば，人口千人に対するめま いの有訴率は，20代·30代では18.0，19.3で，そ の後年齢とともに増加し 65 歳以上では $35.7,75$ 歳 以上では 44.0 となる ${ }^{1)}$ 。高齢者でめまいに悩む人 は多いことが推測されるが，今回の検討では高齢 のめまい患者の比率は高いものの，20代から40代 の患者も依然として多かった。高齢のめまい患者 の受診動態には地域の人口比率や受診への困難さ などの受療特性，あるいは加齢の影響など高齢者 特有の要因が影響を与えるが，高齢化社会がプラ イマリ・ケアの重要な課題である以上，地域に密 着した高齢めまい患者の受診動態の検討は，今後 のめまい診療のために不可欠である。

末梢性めまいが全体の $2 / 3$ を占め，一方で中 枢性めまいの比率は少なかった。関根らによれば 過去の報告における中枢性めまいの頻度は，7〜 $8 \%$ という報告と $15 \%$ 以上という報告とに分けら れるが, そのうち占拠性病変, 脳梗塞, 脳変性・ 萎縮等の画像検査で診断が可能な疾患の頻度は $5 \%$ 前後と各報告に差は認められないとし，中枢 性めまいが15\%を超える報告では椎骨脳底動脈循 環不全などのその他の中枢障害の頻度が高く，そ れが中枢性障害全体の頻度に影響を与えていると している ${ }^{13)}$ 。椎骨脳底動脈循環不全の診断は困難 ことも多く，診断が慎重になるため今回の検討で は椎骨脳底動脈循環不全の頻度は少なかった。関 根らが指摘するように椎骨脳底動脈循環不全は診 断基準が必ずしも確立しておらず13)，施設間の診 断基準の違いが問題である。また，中枢性めまい の場合，めまい以外の意識障害や麻痺などの神経 
症状を伴うこともあり，神経内科・脳外科など総 合病院や大学病院を受診し, 診療所を受診するこ とが少ないことも今回の検討で中枢性めまいの頻 度が低かった原因のひとつであると推測される。 原因疾患で最も多かったのはBPPVであり，次 いでMD が多く，BPPV と MDをあわせると末 梢性めまいの半数以上を占める。耳鼻咽喉科診療 所では，BPPVや MD に代表される末梢性めまい を適切に診療することが重要であることがわか る。

めまい専門外来においても $1 / 4$ から $1 / 3$ は 原因不明といわれるが ${ }^{6}$, 今回の検討でも $17 \%$ の 症例が原因不明であった。また，末梢性・中枢性 以外のめまいのなかでほぼ同数の比率で認められ た頸性めまい・起立性調節障害・心因性めまいは 互いに重なり合う部分もあり, 診断治療が単純に はいかない。また診断基準が明確でない面もあ り, 施設間で診断が一様でないことも多い。これ らがめまいの診療を複雑なものにしている。さら には MD に代表される慢性で反復するめまいや 持続性のめまいでは治療が一様に進まないことも 多く，患者が様々な医療機関を受診するいわゆる “ドクターショッピング”が起こりやすい。今回 の検討でも $60 \%$ 症例はすでにいずれかの医療機 関受診の既往があり，複数の医療機関を受診する 患者が多いことがわかる。診療所・病院ばかりで なく大学病院を受診している症例もあることはめ まい診療の現状の問題点であろう。

過去の受診歴を検討するとめまい症例の受診動 態の一面を推測することができる。診療所・病 院・大学病院は病診連携の面からは一次医療・二 次医療・三次医療である。それぞれの医療機関で の受診動態には差があり興味深い。いずれの医療 機関でもめまい患者は耳鼻咽喉科あるいは内科を 受診しその他の科を受診することは少ない。しか し, 耳鼻咽喉科と内科の比率は医療機関によって 異なっていた。診療所すなわち一次医療, プライ マリ・ケアでは, むしろ内科を受診する患者が多 い。このことは一般住民にはめまいは内科で扱う 病気であるという観念があることを示唆してい る。一方, 病院・大学となるにつれて内科の受診 症例は減少し耳鼻咽喉科の受診症例が増加する。 大学病院ではほとんどの症例が耳鼻咽喉科を受診 している。耳鼻咽喉科に設置されているめまい外
来がこれらの医療機関で十分に機能していること がわかる。プライマリ・ケアの領域ではめまいの 診療が内科で扱われることが多い一方で大学病院 では耳鼻咽喉科がめまいの診療の中心を担ってい る乘離現象は現在のめまい診療の問題点とも言え よう。耳鼻咽喉科, 内科, 脳外科医師のアンケー 卜調査 ${ }^{16)}$ でも，初診のめまい患者を何科が診るべ きかとの質問に対し，耳鼻咽喉科医のほとんどが 内科と答えたという。一方で内科医はめまいの初 期診療は耳鼻咽喉科医がすべきと答えている。め まい患者診療を適切かつ効率的に行うためにもめ まい診療における耳鼻咽喉科医の役割を検討する ことが必要のように思われる。めまい症例の中で 最も多いBPPVでは半数の症例に過去の受診歴 がなかったことは, 診療所でのめまいのプライマ リ・ケアではBPPVの診療が重要であることを 示唆している。これに対して, MDでは過去の受 診歴では耳鼻咽喉科を受診していた患者がほとん どで，MD は治療の主体は専門医によってなされ ていることがわかる。このように原因疾患によっ てもめまい患者の受診動態は異なっている。従来 このような疾患を考慮しためまい患者の受診動態 は詳しく検討されておらず，めまいの効率的な診 療を考える上からも今後の検討課題であろう。

従来の診療圈分析の検討によると，東京のよう な市街地では診療所の所在地を中心とする半径 $500 \mathrm{~m}$ 内に患者の $80 \%$ の居住地があるとされてい る。我々の施設の全症例の診療圈分析では, 半径 $500 \mathrm{~m}$ 内に居住する症例の比率は58\%であ り，80\%を下回っていた。我々の施設の診療圈が 一般の診療所に比べ広いと即断はできない。従来 の診療圈分析が内科を中心になされたものがほと んどで, 耳鼻咽喉科診療所の診療圈が内科診療所 よりも広い可能性もある。しかし，めまい症例に 限ると半径 $500 \mathrm{~m}$ 内に居住する症例の比率は $34 \%$ となり，明らかに診療圈は拡大する。対照と した，アレルギー性鼻炎や急性咽喉頭炎症例と比 較しても同様である。めまいの診療を積極的に行 うことにより診療圈は拡大することを示してい る。

今回の検討は一般耳鼻咽喉科診療所におけるめ まい患者の受診動態をすべて反映するもではない が，プライマリ・ケアにおけるめまい診療は病院 や大学病院のそれとは異なっていると推測され 
る。めまいのプライマリ・ケアは内科医と耳鼻科 咽喉医で担われているが，むしろ内科医が診療す る機会が多い可能性が考えられる。原因疾患で多 い BPPVにせよ，MD にせよ，内耳疾患である以 上耳鼻咽喉科専門医の診療範囲であるが，実際は 内科医が診療することが多い。一方で，教育機関 である大学病院ではめまいの教育・診療が耳鼻咽 喉科でなされている。この乘離はめまいの効率的 な診療に問題となろう。診療所の耳鼻咽喉科専門 医が積極的にめまい診療を行うことによって，診 療の拡大につながるとともにプライマリ・ケアか ら高度な専門医療までの連続しためまい診療が期 待できる。

\section{まとめ}

1. 耳鼻咽喉科診療所におけるめまい患者の受 診動態を検討した。

2. めまい患者数・比率ともに大学病院・地域 病院と同様であった。

3 ．年齢別には20から 70 代の症例が多く，65歳 以上の症例が多いことが推測されたが，さらに高 齢者の受療行動を考慮した検討が必要であると推 測された。

4.末梢性めまいが大半を占め，中枢性めまい は少ない傾向があった。

5. 原因疾患では良性発作性頭位めまい症が最 も多く，次いでメニエール病であった。

6. 原因不明のめまいが $17 \%$ 認められ，これら がめまいの診療を複雑にしていると推測された。

7. 過去に他医療機関を受診したものが半数以 上認められ，めまい患者は複数の医療機関を受診 することが多いものと推測された。

8.めまいの診療は耳鼻咽喉科と内科でほとん ど行われているが，プライマリ・ケアでは内科で 診療されることが多く, 一般病院や大学病院など ではめまいは耳鼻咽喉科で診療されていると推測 された。この靟離がめまいの診療の現状の問題点 と考えられた。

9. 耳鼻咽喉科診療所においても積極的にめま い患者の診療を行うことによって，診療の拡大に つながるとともにプライマリ・ケアから高度な専 門医療までの連続しためまい診療が期待できる。

\section{文献}

1）国民衛生の動向：第29表 有訴者率 厚生の 指標臨時増刊 2005年第52巻第 9 号 406厚
生統計協会

2 ）宇野敦彦，長井美樹，坂田義治，他：市中病 院耳鼻咽喉科における最近のめまい統計。日 耳鼻 $104 ： 1119-1125 ， 2001$

3 ）山中泰輝，岡 亮，大坂正浩，他：当科 14 年間のめまい症例の統計的観察。耳鼻臨床

89：1051-1060，1996

4 ）浅井美洋，松井和夫，野末道彦：当科におけ るめまい症例の統計的観察。耳鼻臨床 84： 589-593，1991

5 ）落合 敦, 徳増厚二, 長沼英明, 他：北里大 学病院めまい外来の最近 3 年間のまとめ 診 断名と患者の年齢について. Equilibrium Res 60: 78-85, 2001

6 ）嘉村恵理子，相原康孝，山口 潤，他：めま い外来 1 万例の統計的検討. 耳喉頭頸 71 : 901-906, 1999

7 ）任 光，佐々木 修，赤平年三，他：当科 に扔けるめまい外来患者の統計的観察。耳鼻 臨床＼cjkstart補冊100：70-74，1999

8 ）渡邊健一, 鈴木香代, 小坂和己, 他：日本医 科大学附属千葉北総病院におけるめまい外来 の統計的検討. 耳喉頭頸 70：435-438, 1998

9 ）林 振堂, 岡田真由美, 馬場広太郎：当科に おけるめまい患者の統計。耳鼻臨床 補冊 70 : 56-63, 1994

10）藤川あかね，藤田信哉，乾 洋史，他：当科 における15年間のめまい患者の統計的観察.

Equilibrium Res 52: 487-495, 1993

11）秋定 健，山本英一，河田 信，他：当科に おけるめまい症例の統計的観察．耳鼻と臨床

$35 ： 63-41,1989$

12）麻木宏栄，生駒尚秋，山本哲夫，他：最近 3 年間の当科外来における「めまい」患者の統 計的観察.耳鼻と臨床 30 (補冊 1 )：282288, 1984

13）関根和教，佐藤 豪，武田憲明：大学病院に おけるめまい症例の統計的検討とめまい疾患 の診断基準の問題点. 日耳鼻 $108: 842-$ 849,2005

14）大和田聡子，石田孝，高野澤美奈子，他：当 科における高齢者めまいについての統計的検 討. Equilibrium Res 64: 203-210, 2005

15）増田圭奈子，五島史行，荒木康智，他：めま 
Equilibrium Res Vol. 67(2)

い診療における耳鼻咽喉科の役割. Equilibrium Res 65: 48-56, 2006

原稿到着：平成19年 7 月 26 日

別刷請求先 : 小林 謙

テ153-0064 東京都目黑区下目黑6-18-26

小林耳鼻咽喉科内科クリニック 